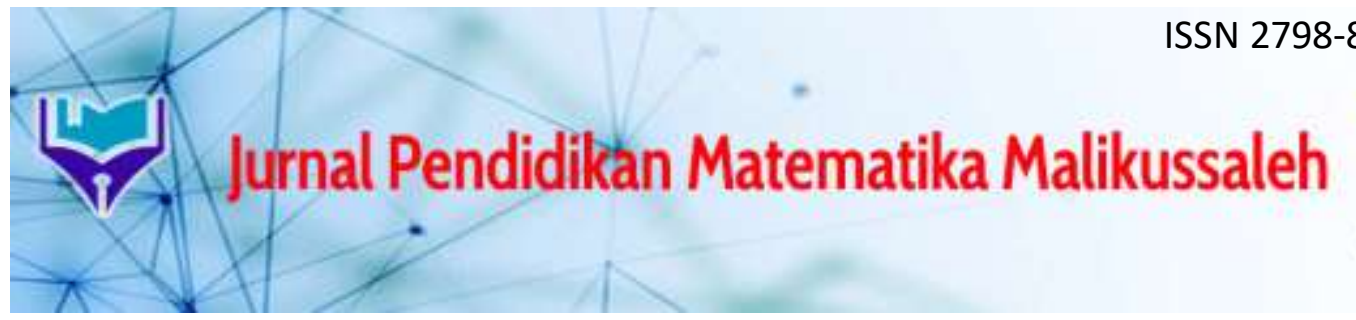

Volume 1, Nomor 2, November 2021

\title{
ANALISIS KESALAHAN SISWA MTsN 2 ACEH UTARA \\ DALAM MENYELESAIKAN SOAL OPERASI BILANGAN BULAT DAN ALTERNATIF PENYELESAIANNYA
}

\author{
Rismayani $^{1)}$, Aklimawati ${ }^{2 *}$, Muliana ${ }^{3)}$ \\ ${ }^{1,2,3}$ Program Studi Pendidikan Matematika, Universitas Malikussaleh, Aceh Utara \\ * Korespondensi Penulis. E-mail : aklimawati@unimal.ac.id
}

\begin{abstract}
Abstrak
Penelitian ini bertujuan untuk mendeskripsikan jenis-jenis kesalahan siswa MTsN 2 Aceh Utara dalam menyelesaikan soal operasi bilangan bulat dan Alternatif penyelesaiannya. Metode penelitian ini merupakan metode deskriptif kualitatif. Teknik pengumpulan data dilakukan menggunakan tes tertulis, wawancara dan dokumentasi. Subjek penelitiaan diambil dari kelas VII F sebanyak 23 siswa. Dari 23 siswa diambil 6 orang siswa yang akan dijadikan informan untuk diwawancarai. Berdasarkan hasil penelitian dapat disimpulkan bahwa jenisjenis kesalahan yang dilakukan oleh siswa MTsN 2 Aceh Utara dalam meyelesaikan soal operasi hitung pada bilangan bulat adalah 1) kesalahan saat melakukan tes, dimana siswa tidak menjawab soal akibat tidak mengerti apa yang ditanyakan, alternatif yang dapat dilakukan yaitu siswa harus sering berlatih mengerjakan soal. 2) kesalahan membaca petunjuk, dimana siswa salah dalam menyelesaikan jawaban dengan benar, kesalahan ini dikarenakan siswa tidak memahami petunjuk dari soal. Alternatif yang dapat dilakukan adalah siswa membaca soal berulang dan benar-benar memahami apa yang ditanyakan. 3) kesalahaan konsep, dimana siswa tidak memahami konsep materi yang terdapat pada suatu soal sehingga melakukan kesalahan dalam menyelesaikan soal tersebut. Alternatif yang dapat dilakukan adalah memberikan Scaffolding yang meghadirkan secara langsung objek pembelajaran. 4) kesalahan kecerobohan, dimana siswa salah menuliskan salah satu komponen soal, kesalahan ini terjadi karena siswa terburu-buru dan lupa. Alternatif yang dapat dilakukan yaitu mengecek kembali lembar jawaban sebelum dikumpul.
\end{abstract}

Kata Kunci: Analisis Kesalahan, Faktor Kesalahan, Alternatif Penyelesaian.

\section{PENDAHULUAN}

Akhir dari proses pembelajaran yang dilakukan di sekolah tidak luput dari evaluasi. Evaluasi dilakukan dengan memberikan soal kepada siswa untuk mengukur kemampuan yang dimiliki oleh siswa tentang materi yang telah disajikan. Namun dari hasil tes tidak selalu memuaskan, siswa tidak selalu benar dan seringkali melakukan kesalahan dalam menyelesaikan soal tes yang diberikan guru. Kesalahan belajar siswa harus segera diselesaikan secara tuntas, sebab bila kesalahan yang dilakukan siswa tetap dibiarkan maka siswa akan menganggap benar sehingga kesalahan yang dilakukan akan terus diulangi.

Kekeliruan atau kesalahan umum yang sering dilakukan siswa dalam menyelesaikan soal-soal matematika diantaranya adalah kesalahan dalam memahami konsep matematika, kesalahan dalam menggunakan rumus matematika, kekeliruan dalam menghitung, kesalahan 

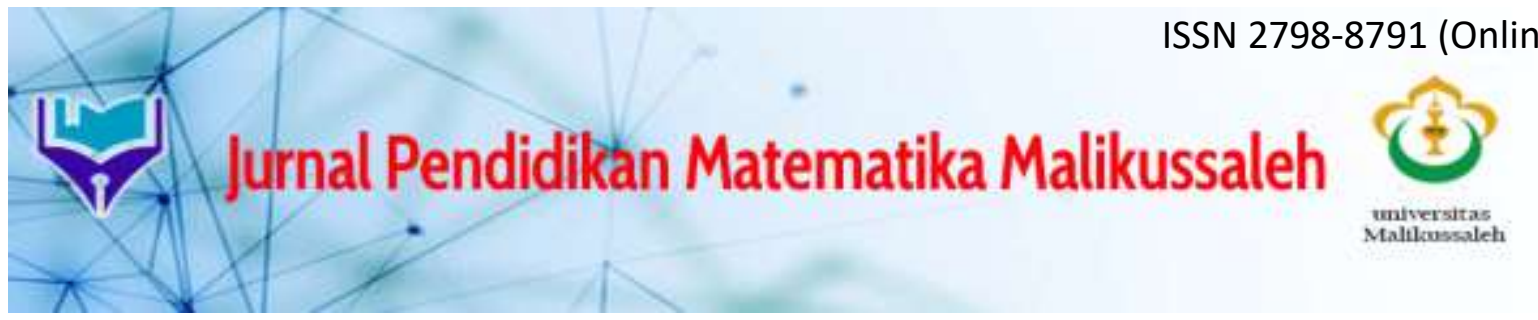

\section{Volume 1, Nomor 2, November 2021}

dalam memahami simbol dan tanda, kesalahan dalam memilih dan kesalahan dalam prosedur penyelesaian (Marpaung, 2018).

Menurut (Susanto., 2017) kesalahan merupakan bentuk penyimpangan pada suatu hal yang telah dianggap benar atau bentuk penyimpangan terhadap suatu yang telah disepakati atau ditetapkan sebelumnya. Menurut Sahriah (Maulidiya, 2019) kesalahan merupakan penyimpangan terhadap hal yang benar yang sifatnya sistematis, konsisten, maupun incidental pada daerah tertentu. Menurut (Ahmad, 2018) kesalahan merupakan bentuk suatu penyimpangan dari suatu kebenaran prosedur yang telah ditetapkan sebelumnya. Berdasarkan beberapa pendapat ahli maka dapat disimpulkan kesalahan merupakan bentuk suatu penyimpangan terhadap suatu hal yang benar yang telah ditentukan.

Menurut (Yunia, 2020) analisis kesalahan adalah sebuah upaya penyelidikan terhadap suatu peristiwa penyimpangan untuk mencari tau apa yang menyebabkan suatu peristiwa penyimpangan itu bisa terjadi. Menurut (Kartini \& Meldawati, 2020) analisis kesalahan adalah pendeskripsian jenis-jenis kesalahan yang dilakukan oleh siswa dan alasan-alasan tentang penyebab terjadinya kesalahan. Analisis kesalahan memiliki tujuan untuk mengetahui keadaan yang sebenarnya, analisis kesalahan juga sebagai prosedur kerja yang mempunyai langkah-langkah tertentu. Adapun langkah-langkah tersebut yaitu, Mengoreksi hasil pekerjaan siswa, Mendeskripsikan banyak kesalahan setiap siswa, Mendeskripsikan jenis kesalahan tiap butir soal, Menghitung presentase jumlah siswa tiap kesalahannya, dan Menyimpulkan.

Menurut teori Nolting (Aroysi, 2018) ada beberapa jenis kesalahan yang dilakukan oleh siswa dalam menyelesaikan soal, antara lain yaitu, Kesalahan saat melakukan tes, Kesalahan membaca petunjuk, Kesalahan konsep, Kesalahan kecerobohan. Adapun jenis kesalahan yang dianalisis dalam penelitian ini adalah analisis kesalahan menurut teori Nolting, yaitu kesalahan saat melakukan tes, kesalahan membaca petunjuk, kesalahan konsep dan kesalahan kecerobohan.

Kesalahan sebenarnya hal yang wajar dilakukan, namun apabila kekeliruan yang dilakukan cukup banyak dan berkelanjutan, maka diperlukan penanganan. Begitu juga dalam mempelajari matematika, merupakan hal yang wajar apabila dalam menyelesaikan soal matematika siswa melakukan kekeliruan ataupun kesalahan. Mengingat dalam pelajaran matematika, materi yang telah diberikan akan saling terkait dan saling menunjang bagi materi berikutnya (Marpaung, 2018)). Maka oleh sebab itu perlu kita analisis kesalahan-kesalahan yang dilakukan siswa untuk dapat menemukan solusi alternatifnya.

Menurut (Basri, 2019) dalam dunia pendidikan tentu saja analisis siswa dalam melakukan kesalahan sangatlah penting, karena hal itu merupakan salah satu modal bagi guru untuk melakukan evaluasi terkait metode pembelajaran yang dilakukan oleh siswa. Namun demikian harus diimbangi dengan pemberian bantuan (Scaffolding) yang sangat diperlukan agar siswa tidak melakukan kesalahan yang serupa atau mengalami misconception.

Kekeliruan atau kesalahan siswa juga sering terjadi pada materi Bilangan bulat. Bilangan bulat juga merupakan materi yang fundamental dan berkesinambungan, karena konsep yang satu dengan konsep yang lain saling berhubungan dan merupakan konsep dasar dan prasyarat bagi materi lain, seperti aljabar, sistem persamaan linear satu variabel, sistem persamaan linear dua variabel dan lain-lain.

Bilangan bulat merupakan materi dasar matematika yang memiliki beberapa sub bab materi, antara lain yaitu operasi penjumlahan dan pengurangan pada bilangan bulat, perkalian 


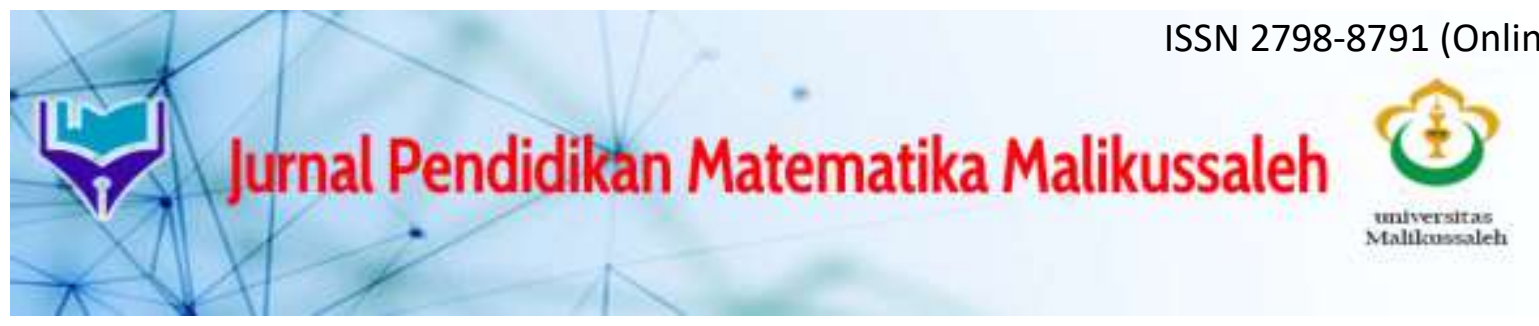

\section{Volume 1, Nomor 2, November 2021}

bilangan bulat, pembagian bilangan bulat, dan pemangkatan bilangan bulat. Berdasarkan penjelasan tersebut perlu diketahui jenis-jenis kesalahan dan penyebab-penyebab terjadinya kesalahan yang dilakukan oleh siswa beserta solusi alternatif dalam mengatasi masalah tersebut sehingga peneliti tertarik untuk melakukan penelitian dengan judul "Analisis Kesalahan Siswa MTsN 2 Aceh Utara dalam Menyelesaikan Soal Operasi Hitung Bilangan Bulat dan Alternatif Penyelesaiannya".

\section{METODE}

\section{Jenis Penelitian}

Penelitian ini menggunakan jenis penelitian deskriptif kualitatif. Jenis penelitian yang digunakan dalam penelitian ini bertujuan untuk menganalisis data yang berupa kesalahan siswa MTsN 2 Aceh Utara dalam menyelesaikan soal operasi bilangan bulat. Hasil temuan analisis kesalahan siswa tersebut, kemudian dideskripsikan berdasarkan pendekatan deskriptif.

\section{Waktu dan Tempat Penelitian}

Penelitian dilakukan pada semester 2 tahun ajaran 2020/2021. Tempat pelaksanaan penelitian ini adalah di MTsN 2 Aceh Utara kelas VII yang beralamat di jalan Medan Banda Aceh, Desa Uteun Geulinggang, Kecamatan Dewantara, Kabupaten Aceh Utara, Provinsi Aceh.

\section{Target/SubjekPenelitian}

Subjek penelitian untuk memperoleh informasi yang diambil dari satu kelas yaitu terdiri atas 23 siswa, yaitu kelas VII-F MTsN 2 Aceh Utara Tahun Ajaran 2020/2021. kemudian peneliti melakukan wawancara terhadap 6 siswa sebagai informan (yang memberi informasi).

\section{Prosedur}

Prosedur dalam penelitian ini terdiri dari beberapa langkah antara lain sebagai berikut:

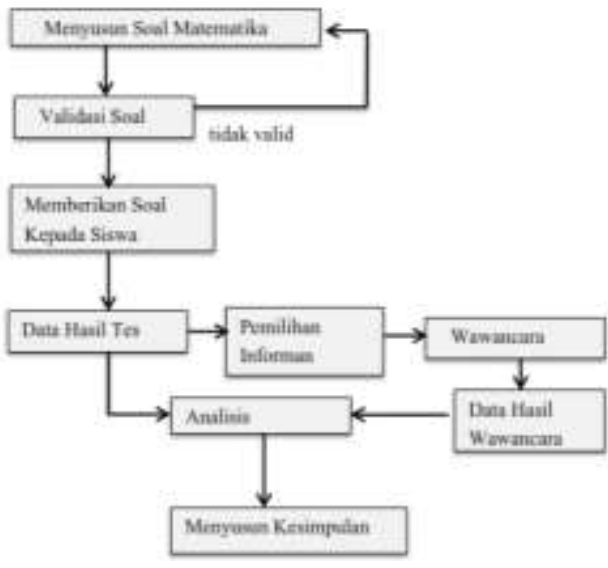

Gambar 1. Bagan Prosedur Penelitian 


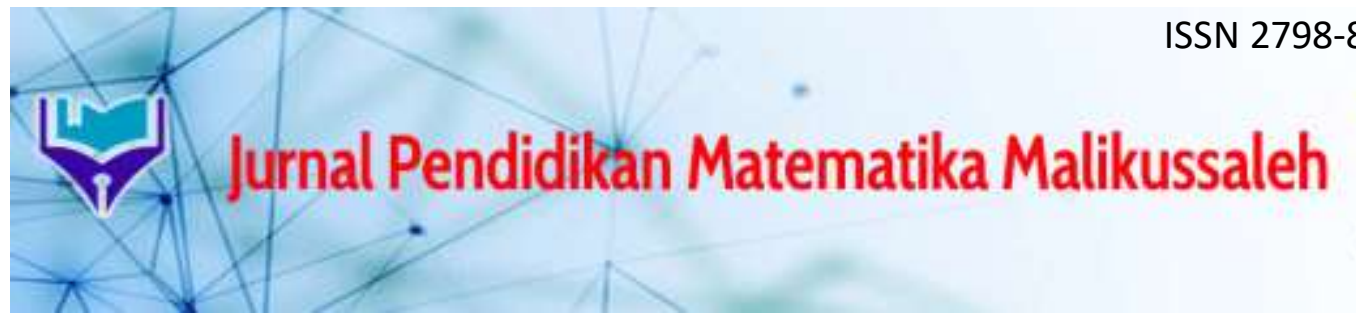

Volume 1, Nomor 2, November 2021

Data, Intrumen, dan Teknik Pengumpulan Data

Jenis data yang dikumpulkan dalam penelitian ini data kualitatif berupa hasil lembar jawaban siswa dalam menyelesaikan soal tes materi operasi bilangan bulat dan hasil wawancara siswa. Instrumen dalam penelitian ini adalah soal tes materi operasi bilangan bulat dan pertanyaan wawancara. Teknik pengumpulan data dengan melakukan Tes Tertulis. Pada penelitian ini tes dilakukan untuk mengetahui kesalahan-kesalahan yang terjadi pada siswa kelas VII MTsN 2 Aceh Utara ketika menjawab soal-soal materi operasi bilangan bulat. Teknik berikutnya adalah Dokumentasi. Selanjutnya Wawancara/interview. Wawancara yang digunakan dalam penelitian ini adalah wawancara semiterstruktur (Semistructure Interview).

\section{Teknik Analisis Data}

1. Data Reduction (Reduksi Data)

Dalam penelitian ini data yang diperoleh berupa hasil pekerjaan siswa yang akan dipilih hal-hal pokok saja. Karena penelitian ini bertujuan mengetahui kesalahan siswa dalam menyelesaikan soal operasi bilangan bulat, maka hal pokok yang dimaksud adalah bagian pekerjaan siswa yang terdapat kesalahannya.

2. Data Display (Penyajian Data)

Data dalam penelitian ini akan disajikan dalam bentuk teks naratif yang merupakan penjelasan dari hasil yang dilakukan peneliti terhadap kesalahan siswa.

3. Conclusion Drawing/Verification

Dalam penelitian ini kesimpulan ditarik berdasarkan hasil analisis terhadap data hasil pekerjaan siswa.

4. Uji Keabsahan Data

Dalam penelitian ini triangulasi yang digunakan yaitu triangulasi teknik.Triangulasi teknik dilakukan dengan cara membandingkan data yang dihasilkandari beberapa teknik yang berbeda, yang digunakan dalam penelitian. Contoh membandingkan data hasil observasi dengan data hasil wawancara, data hasil observasi dengan data dokumentasi atau data hasil wawancara dengan data hasil dokumentasi.

\section{HASIL DAN PEMBAHASAN}

\section{a. Deskripsi Kesalahan}

Setelah diberikan tes kepada siswa, selanjutnya peneliti memeriksa dan mengkaji jawaban para siswa. Dari jawaban tersebut peneliti dapat mengetahui kesalahan-kesalahan yang dilakukan siswa dalam menyelesaikan soal materi penjumlahan dan pengurangan bilangan bulat. Berikut ini tabel deskripsi kesalahan pada jawaban siswa sebagai berikut:

Tabel 1. Deskripsi Kesalahan pada Penyelesaian Soal Materi Bilangan Bulat

\begin{tabular}{|l|l|l|c|c|c|c|}
\hline \multirow{1}{*}{$\begin{array}{c}\text { Jenis } \\
\text { Kesalahan }\end{array}$} & $\begin{array}{c}\text { Letak Kesalahan } \\
\text { Siswa }\end{array}$ & $\begin{array}{c}\text { Nomor } \\
\text { Presensi } \\
\text { untuk } \\
\text { Soal } \\
\text { No. 1 }\end{array}$ & $\begin{array}{c}\text { Nomor } \\
\text { Presensi } \\
\text { untuk } \\
\text { Soal } \\
\text { No. 2 }\end{array}$ & $\begin{array}{c}\text { Nomor } \\
\text { Presensi } \\
\text { untuk } \\
\text { Soal } \\
\text { No. 3 }\end{array}$ & $\begin{array}{c}\text { Nomor } \\
\text { Presensi } \\
\text { untuk } \\
\text { Soal No. } \\
\mathbf{4}\end{array}$ & $\begin{array}{c}\text { Nomor } \\
\text { Presensi } \\
\text { untuk } \\
\text { Soal No. } \\
\mathbf{5}\end{array}$ \\
\hline $\begin{array}{l}\text { Kesalahan } \\
\text { saat } \\
\text { Melakukan }\end{array}$ & $\begin{array}{l}\text { Siswa mengosongkan } \\
\text { jawaban dan tidak } \\
\text { menyelesaikan semua }\end{array}$ & $4,6,19$ & $3,4,6$, & $4,6,9$, & $1,4,11$, & $1,9,11$, \\
& & 19 & 19 & 13,14 & 13.14 \\
\hline
\end{tabular}



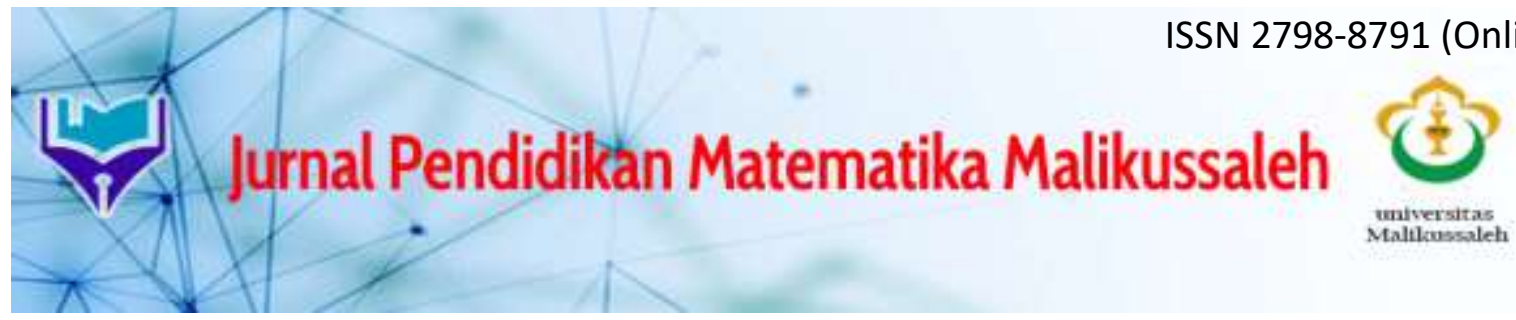

Volume 1, Nomor 2, November 2021

\begin{tabular}{|c|c|c|c|c|c|c|}
\hline Tes (K1) & langkah penyelesaian, & & & & & \\
\hline $\begin{array}{l}\text { Kesalahan } \\
\text { Membaca } \\
\text { Petunjuk } \\
\text { (K2) }\end{array}$ & $\begin{array}{l}\text { Siswa salah perintah } \\
\text { soal atau tidak } \\
\text { memahami petunjuk } \\
\text { soal, tidak memahami } \\
\text { penyelesaian dengan } \\
\text { benar dan } \\
\text { mengerjakan soal asal- } \\
\text { asalan. }\end{array}$ & $1,11,14$ & - & $\begin{array}{l}1,10, \\
11,14 \\
16,23\end{array}$ & $6,9,19$ & $\begin{array}{l}4,6,8, \\
21,23\end{array}$ \\
\hline $\begin{array}{l}\text { Kesalahan } \\
\text { Konsep } \\
\text { (K3) }\end{array}$ & $\begin{array}{l}\text { Siswa tidak } \\
\text { menguasai konsep dan } \\
\text { salah pengaplikasian } \\
\text { suatu sifat atau rumus }\end{array}$ & 13 & - & - & $\begin{array}{l}2,5,8 \\
10,15 \\
16,22 \\
23\end{array}$ & $\begin{array}{l}2,3,5 \\
10,12 \\
13,15 \\
17,22\end{array}$ \\
\hline $\begin{array}{l}\text { Kesalahan } \\
\text { Kecerobohan } \\
\text { (K4) }\end{array}$ & $\begin{array}{l}\text { Siswa salah } \\
\text { menuliskan tanda } \\
\text { operasi tidak } \\
\text { menuliskan salah satu } \\
\text { komponen soal, salah } \\
\text { menghitung. }\end{array}$ & - & $\begin{array}{l}1,2,9, \\
10,14, \\
16,17 \\
21,23\end{array}$ & - & 3,21 & $7,16,19$ \\
\hline
\end{tabular}

Jadi dari keseluruhan soal tes yang diberikan kepada siswa dapat disimpulkan bahwa jenis kesalahan K1 yang dilakukan oleh siswa sebanyak 11 siswa dari 21 siswa, jenis kesalahan K2 sebanyak 13 siswa dari 21 siswa, jenis kesalahan K3 sebanyak 13 siswa dai 21 siswa dan jenis kesalahan siswa K4 sebanyak 16 siswa dari 21 siswa. Dan kesalahan terbanyak yang dilakukan oleh siswa yaitu pada jenis kesalahan K3 sebanyak 15 siswa.

\section{b. Hasil Wawancara}

Hasil analisis jawaban siswa yang dilakukan peneliti, tidak selamanya memberikan jawaban benar. Mungkin saja kesalahan yang peneliti kemukakan dalam analisis kesalahan jawaban siswa tidak sesuai dengan apa yang dipikirkan oleh siswa yang bersangkutan. Oleh sebab itu peneliti perlu melakukan wawancara terhadap sumber data yang dipilih berdasarkan kesalahan teori nolting dan berdasarkan kemampuan siswa (2 siswa yang mempunyai kemampuan tinggi, 2 siswa yang mempunyai kemampuan sedang dan 2 siswa yang mempunyai kemampuan rendah). Wawancara ini dilakukan tarhadap 6 informan dengan kesalahan yang bervariasi dan paling banyak mewakili setiap jenis kesalahan yang ada. Berikut ini disajikan salah satu petikan wawancara dari 6 informan yang dipilih dan dilanjutkan dengan analisis wawancara. Wawancara siswa yang mempunyai kemampuan tinggi. wawancara antara peneliti (P) dengan informan P15. Petikan wawancara ini untuk mengklarifikasi jawaban dan menggali informasi tentang penyebab terjadinya kesalahan pada soal nomor 4.

$$
\begin{array}{ll}
\text { P } & : \text { "Assalamualaikum P15" } \\
\text { P15 } & \text { "Waalaikumslam" } \\
\text { P } & \text { : Apa kabar P15" } \\
\text { P15 : "Alhamdulillah Baik" }
\end{array}
$$




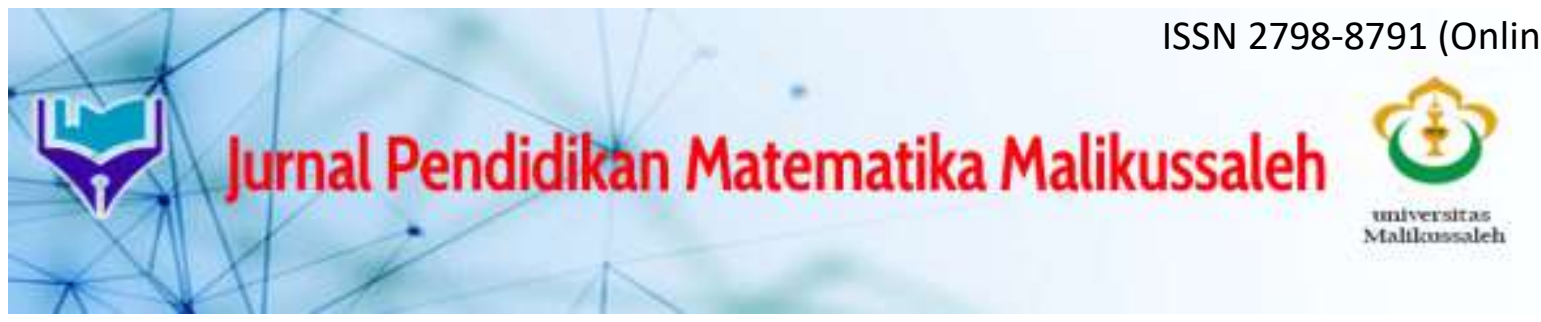

\section{Volume 1, Nomor 2, November 2021}

P : " Alhamdulillah baik ya, nah pada hari ini ibu ingin mewawancarai P15 tentang penyelesaian soal operasi penjumlahan dan pengurangan bilangan bulat yang ibu berikan kemarin, ibu mau nanya P15 suka tidak,belajar matematika?"

P15 : "Alhamdulillah suka bu"

P : "Alhamdulillah suka, berarti senang ya belajar matematika !, mengenai penyelesaian soal yang ibu berikan kemarin, apakah ada kesulitan?"

P15 : "Ada sedikit"

P : :Dimana letak kesulitannya?"

P15 : "Di nomor 5"

P : "Lainnya?"

P15 : "Di nomor 3"

P : :Coba, P15 perhatikan soal nomor 3, dimana letak kesulitannya?"

P15 : "Karenakan, pertama mikirnyakan, kalau misalnya kita buat min 5 ('-5') ini, bakal hasilnya min (-) juga, rupanya salah karena inikan 11 lebih besar jadi hasilnya positif. Disitu letak kesulitannya".

P : "Tapi jawabannya?"

P15 : "-5 bu"

$\mathrm{P} \quad$ : "Ok, ibu mau nanya soal nomor 4, samakan soalnya dengan nomor 3, apakah menurut P15 jawabannya sudah benar?"

P15 : “(menghitung)

P : :Pertanyaan mengerti?"

P15 : "Mengerti bu"

$\mathrm{P} \quad$ : "Coba P15 lihat soalnya (menunjukan soal)

P15 : "(membaca soal)"

P : : Coba lihat jawaban P15, apakah benar jawaban P15?"

P15 : "Salah sepertinya"

P : :Kenapa salah?"

P15 : "Karenakan 6 ini lebih besar munkin hasilnya positif (menghitung )"

P : :Benar jawabannya?"

P15 : "Salah bu"

P : : "Kenapa P15 bisa menjawab seperti disini (menunjuk ke jawaban P15) -6?"

P15 : "6 bu"

P : : "Oo 6, yyy, kenapa 6?

P15 : "Karena $-2-6=-4$ hasilnya"

$P \quad:$ : "-2-6 = -4, benar ini hasilnya?"

P15 : "Sepertinya 4 bu"

P : "Benar?"

P15 : "Nggak tau juga bu"

P : "Ngga tau"

P15 : "Mungkin (bingung)

$\mathrm{P} \quad$ : " Lihat tanda ini (menunjuk kesoal), mengerti?"

P15 : "Kurang"

P : "Ngga ngerti"

P15 : "Iya" 


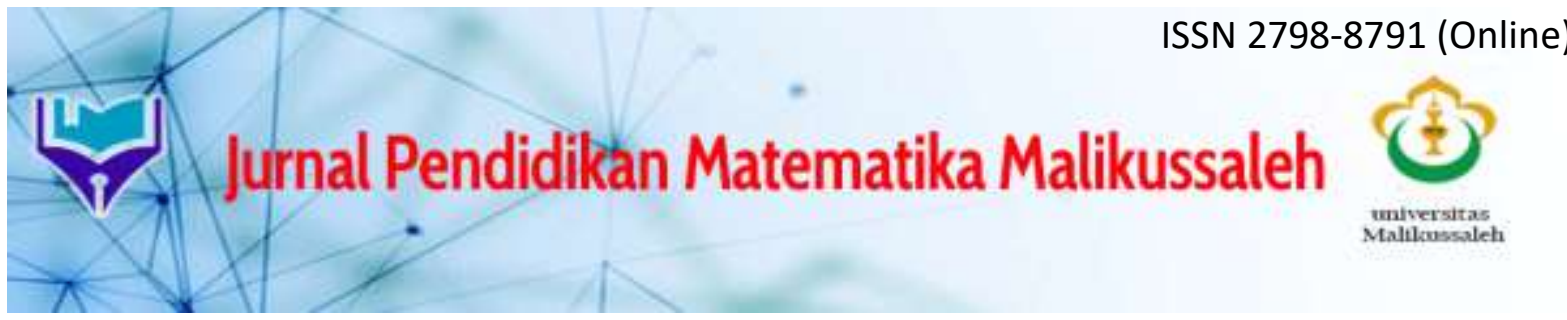

\section{Volume 1, Nomor 2, November 2021}

Dari petikan wawancara tersebut siswa P15 memahami jika ada bilangan negatif dikurangkan dengan bilangan bilangan yang lebih besar maka hasilnya bilangan positif. Hal ini terjadi karena siswa P15 tidak memahami operasi pengurangan pada bilangan bulat yang memuat tanda negatif. Hal tersebutlah yang membuat terjadinya kesalahan dalam penyelesaian soal tersebut. Kesalahan yang dilakukan oleh P15 disebut kesalahan konsep.

\section{c. Pembahasan Hasil Analisis Data}

Secara keseluruhan, dapat dilihat bahwa semua subjek penelitian melakukan kesalahan pada soal yang diberikan, meskipun tidak semua soal yang mereka kerjakan secara salah. Berikut ini pembahasan tentang kesalahan yang dilakukan oleh subyek penelitian yang dijadikan informan berdasarkan kemampuan yang dimiliki oleh siswa tersebut.

Berdasarkan kemampuan yang dimiliki oleh setiap siswa tersebut, informan yang diambil sebanyak 2 siswa masing-masing kelompok/kemampuan. Siswa yang berkemampuan tinggi diambil sebanyak 2 siswa, siswa yang berkemampuan sedang diambil sebanyak 2 siswa dan siswa yang berkemampuan rendah sebanyak 2 siswa.

Pertanyaan wawancara yang diajukan sesuai dengan kesalahan penyelesaian soal yang dikerjakan oleh siswa kelas VII-F. Dari hasil analisis data yang meliputi reduksi data, penyajian data, dan verifikasi data maka diperoleh jenis-jenis kesalahan yang dilakukan siswa dalam menyelesaikan soal-soal pada materi operasi penjumlahan dan pengurangan bilangan bulat beserta faktor penyebabnya. Adapun jenis-jenis kesalahan beserta faktor penyebabnya adalah sebagai berikut:

1. Siswa yang memiliki kemampuan tinggi

Untuk siswa yang memiliki kemampuan tinggi diambil sebanyak 2 informan, analisa kesalahan-kesalahan yang dilakukan oleh siswa tersebut adalah sebagai berikut:

a). Kesalahan konsep

Kesalahan konsep yaitu kesalahan yang dilakukan oleh siswa yang memiliki kemampuan tinggi dengan presensi 15 (P15) pada soal nomor 3 dan 5 dan siswa dengan presensi 17 (P17) pada soal nomor 5. Pada kesalahan ini kedua siswa tersebut sama-sama salah dalam mengoperasikan bilangan yang memuat tanda negatif. Kedua siswa tersebut beranggapan $-\mathrm{a}=\mathrm{a}$, kedua siswa tersebut melakukan kesalahan konsep dikarenakan keduanya tidak memahami permasalahan yang terdapat pada soal terkhususnya pada operasi penjumlahan dan pengurangan bilangan bulat negatif.

b). Kesalahan kecerobohan

Kesalahan kecerobohan yaitu kesalahan yang dilakukan oleh siswa yang memiliki kemampuan tinggi dengan presensi 17 (P17) pada soal nomor 2. Pada soal nomor P17 salah menulis tanda operasi dalam penyelesaiannya. Tanda operasi yang terdapat pada soal berupa operasi pengurangan akan tetapi P17 menulis tanda operasi penjumlahan. Kesalahan ini dilakukan oleh P17 dikarenakan P17 terburu-buru dalam menyelesaikan soal tersebut.

2. Siswa yang memiliki kemampuan sedang

Untuk siswa yang memiliki kemampuan sedang diambil sebanyak 2 informan, analisa kesalahan-kesalahan yang dilakukan oleh siswa tersebut adalah sebagai berikut:

a). Kesalahan saat melakukan tes

Kesalahan saat melakukan tes yaitu kesalahan yang dilakukan oleh siswa dengan presensi 11 (P11) pada soal nomor 4, 5, dan 6. Pada soal tersebut P11 tidak menjawab soal 


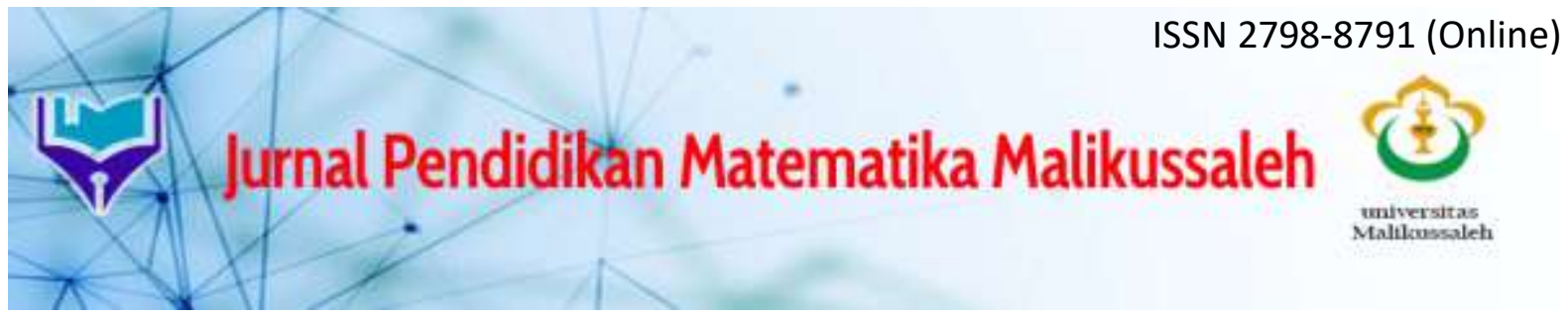

Volume 1, Nomor 2, November 2021

atau mengosongkan jawaban. Kesalahan ini dilakukan oleh P11 dikarenakan siswa tidak mengetahui perintah soal.

b). Kesalahan membaca petunjuk

Kesalahan membaca petunjuk yaitu kesalahan yang dilakukan oleh siswa dengan presensi 11 (P11) dan presensi 23 (P23) pada soal nomor 3 dan 6. P11 melakukan kesalahan pada soal nomor 3. Pada soal nomor 3 siswa P11 langsung menjawab soal dalam satu langkah, padahal dalam penyelesaian soal tersebut lebih dari satu langkah kecuali siswa langsung mengsubtitusikan jawaban pada nilai X yang ditanyakan pada soal. Kesalahan tersebut dilakukan oleh siswa P11 dikarenakan siswa lupa dengan langkah penyelesaian soal tersebut.

c). Kesalahan konsep

Kesalahan konsep yaitu kesalahan yang dilakukan oleh siswa dengan presensi 23 (P23) pada soal nomor 4. Pada soal nomor 4 siswa P23 salah dalam mengoperasikan bilangan yang memuat tanda negatif. Siswa P23 tidak memahami maksud tanda negatif yang terdapat pada suatu bilangan. Kesalahan ini dilakukan oleh P23 karena P23 tidak memahami konsep pengoperasian pada bilangan bulat negatif.

d). Kesalahan Kecerobohan

Kesalahan kecerobohan yaitu kesalahan yang dilakukan oleh dengan presensi 23 (P23) pada soal nomor 6. Pada soal tersebut siswa P23 salah menuliskan komponen soal, yang soal nomor 6 yeng benar adalah -32-18+(-17) sedangkan P23 menulis -36-18+(-17). Kesalahan ini dilakukan oleh siswa dikarenakan siswa kurang teliti dalam membaca soal.

3. Siswa yang memiliki kemampuan rendah

Untuk siswa yang memiliki kemampuan sedang diambil sebanyak 2 informan, analisa kesalahan-kesalahan yang dilakukan oleh siswa tersebut adalah Kesalahan membaca petunjuk.

Kesalahan membaca petunjuk yaitu kesalahan yang dilakukan oleh siswa dengan presensi 5 (P5) dan presensi 12 (P12). Kesalahan tersebut dilakukan pada soal nomor 5 dan 6 dan nomor 4 dan 6. P5 melakukan kesalahan tersebut dikarenakan tidak memahami apa yang ditanyakan sehingga siswa menjawab secara asal-asalan. Sedangkan P12 melakukan kesalahan tersebut dikarenakan tidak mengerti dengan perintah soal.

\section{d. Alternatif Penyelesaian}

Berdasarkan jenis kesalahan dan faktor-faktor terjadinya kesalahan yang dilakukan oleh siswa MTsN 2 Aceh Utara, maka dapat ditemukan alternatif atau solusi yang digunakan untuk mengatasi permasalahan tersebut. Adapun alternatif tersebut adalah sebagai berikut:

1. Kesalahan Saat Melakukan Tes

Adapun alternatif dalam mengatasi kesalahan saat melakukan tes yang dilakukan oleh siswa MTsN 2 Aceh Utara dalam menyelesaikan soal operasi penjumlahan dan pengurangan bilangan bulat adalah sebagai berikut:

a) Guru mengontrol siswa ketika proses penyelesaian soal supaya guru dapat melakukan pendampingan lebih terhadap siswa yang tidak menyelesaikan jawaban atau mengosongkan jawaban.

b) Guru memberi kesempatan kepada siswa untuk menanyakan perihal yang tidak dipahami pada soal. 


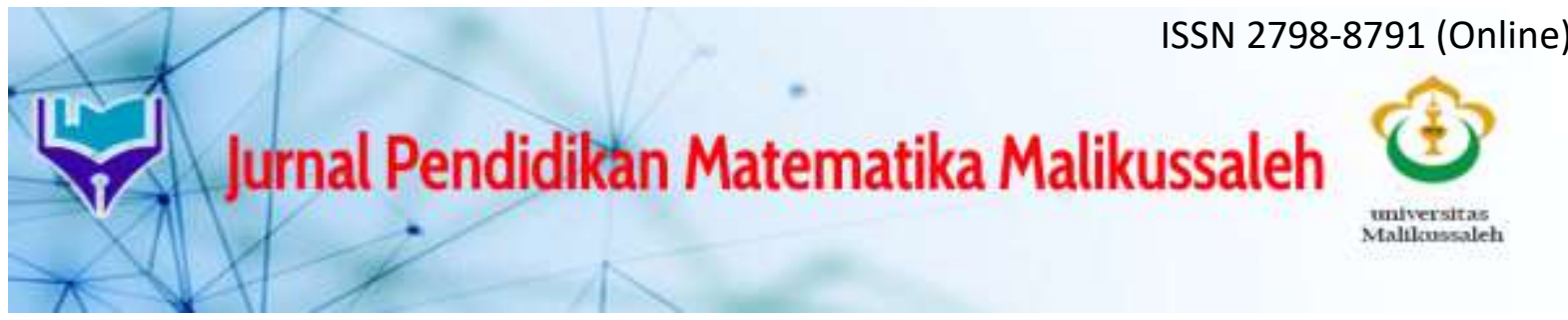

\section{Volume 1, Nomor 2, November 2021}

2. Kesalahan Membaca Petunjuk

Adapun alternatif dalam mengatasi kesalahan membaca petunjuk yang dilakukan oleh siswa MTsN 2 Aceh Utara dalam menyelesaikan soal operasi penjumlahan dan pengurangan bilangan bulat adalah sebagai berikut:

a) Guru sebaiknya memberikan soal latihan kepada siswa secara berkelompok kemudian jawaban dari soal tersebut dipresentasikan di depan kelas. Hal tersebut dilakukan untuk mengetahui langkah-langkah penyelesaian soal yang benar dan lengkap. Jika dalam penyelesaian suatu soal terdapat beberapa langkah dan siswa yang mempresentasikan jawaban tersebut menghilangkan salah satu langkah atau lebih maka guru menanyakan hasil setelah langkah yang dihilangkan tersebut dari mana agar siswa yang lain juga mengetahuinya.

b) Setiap guru memberikan soal kepada siswa, sebaiknya guru selalu menekankan kepada siswa untuk membaca soal lebih dari satu kali agar siswa benar-benar memahami permasalahan yang terdapat pada soal dan benar-benar mengetahui apa yang ditanyakan pada soal.

c) Guru harus melatih siswa dengan soal yang bersifat berpikir kritis agar siswa terbiasa

3. Kesalahan Konsep

Adapun alternatif dalam mengatasi kesalahan konsep yang dilakukan oleh siswa MTsN

2 Aceh Utara dalam menyelesaikan soal operasi penjumlahan dan pengurangan bilangan bulat adalah sebagai berikut:

a) Pada proses pembelajaran guru sebaiknya menggunakan model pembelajaran yang dapat mengaitkan materi penjumlahan dan pengurangan bilangan bulat dengan kehidupan sehari-hari supaya siswa mudah mengingat konsep-konsep pelajaran.

b) Mengaplikasikan media pembelajaran yang unik dan menarik berupa alat peraga agar siswa mudah menangkap materi penjumlahan dan pengurangan bilangan bulat dan mudah dalam memainkan media tersebut, contohnya kereta bilangan (Motif dari garis bilangan).

c) Memberikan Scaffolding yang meghadirkan secara langsung objek bilangan negatif dan positif dengan menggunakan kartu bilangan khususnya bagi yang tidak mengerti maksud dari tanda negatif pada suatu bilangan

4. Kesalahan Kecerobohan

Adapun alternatif dalam mengatasi kesalahan kecerobohan yang dilakukan oleh siswa MTsN 2 Aceh Utara dalam menyelesaikan soal operasi penjumlahan dan pengurangan bilangan bulat adalah sebagai berikut:

a) Ketika guru memberikan soal kepada siswa, guru menekankan siswa agar mengecek kembali lembaran jawaban sebelum dikumpulkan kepada guru.

b) Guru harus mengingatkan dan menekankan kepada siswa agar benar-benar teliti dalam mengerjakan soal dan guru memberikan waktu yang sesuai dengan jumlah soal yang diberikan dan tingkat kesukaran soal yang diberikan. Hal ini dilakukan agar siswa tidak terburu-buru dalam mengerjakan soal.

\section{KESIMPULAN}

Kesimpulan dari penelitian ini adalah terdapat beberapa kesalahan yang dilakukan siswa dalam menyelesaikan soal tes operasi bilangan bulat. Adapaun kesalahan yang 


\section{Volume 1, Nomor 2, November 2021}

dilakukan siswa berupa Kesalahan konsep, Kesalahan kecerobohan, Kesalahan membaca petunjuk, Kesalahan saat melakukan tes.

\section{DAFTAR PUSTAKA}

Ahmad, D. M. (2018). Analisis Kesalahan Siswa dalam Menyelesaikan Soal Cerita Materi Perbandingan di Kelas VII SMP. Jurnal Pendidikan dan Pembelajaran Khatulistiwa, 7(1):, (https://jurnal.untan.ac.id).

Aroysi, G. (2018). Analisis Kesalahan Siswa Dalam Menyelesaikan Soal Bertipe PISA Berdasarkan Teori Nolting. Jakarta: (Skripsi). Universitas Islam Negeri Syarif Hidayatullah.

Basri, H. H. (2019). Analisis Kesalahan Siswa dan Pemberian Scaffolding Pada Materi Operasi Bilangan Bulat. Jurnal Kependidikan Dasar Islam Berbasis Sains, 4(2):207216, (DOI: https://doi.org/10.21154/ibriez.v4i2.

Kartini, \& Meldawati. (2020). Analisis Kesalahan Siswa Kelas VII SMP Dalam Menyelesaikan Soal Matematika Pada Materi Bilangan Berpangkat Bulat Positif. Jurnal Pendidikan dan Matematika, 14(1):1-14, (doi :10.30821/axiom.v10i1.7681).

Marpaung, N. R. (2018). Analisis Kesalahan Siswa Dalam Menyelesaikan Soal Matematika DI MTs Swasta Aisyiyah Sumatera Utara. Medan: Universitas Islam Negeri Sumatera Utara.

Maulidiya, D. M. (2019). Faktor-faktor Penyebab Kesalahan Siswa Dalam Menyelesaikan Soal Luas Permukaan Kubus dan Balok. JPPMS, 3(3):342-352, (DOI:10.33369/jp2ms.3.3.342-352).

Susanto., A. F. (2017). Analisis Kesalahan Siswa Dalam Menyelesaikan Soal Cerita Matematika Berdasarkan Tahapan Newman Beserta Bentuk Scaffoding Yang Diberikan. Jurnal Kadikma, 8(1):40-51.(DOI: https://doi.org/10.19184/kdma.v8i1.5).

Yunia, N. Z. (2020). Kesalahan Siswa SMP Dalam Menyelesaikan Soal Cerita Pada Materi Aritmatika Sosial. Jurnal Teorema, 5(1): 105-116. (DOI: http://dx.doi.org/1025157/teorema.v5i1.3206). 